\title{
THE WORLD HEALTH ORGANIZATION
}

$\mathrm{T}$

HE annual report of the Director-General of the World Health Organization for 1959 shows the wide range of the assistance given by the Organization to countries throughout the world, both directly in the form of projects adapted to particular needs, and through international technical services of the more traditional type*.

The 'project list', occupying more than half the volume, gives particulars of the projects, numbering more than 500, in which the World Health Organization has been co-operating with the Governments of some 140 countries, sometimes in conjunction with other organizations. A summary narrative for each project states its aim, the nature of the assistance and progross made during the year, and adds, whero possible, an assessment of the results obtained. The list, grouped by country and subject title under each of the six regions of the World Health Organization, includes inter-country and inter-regional projects in which help is given to groups of countries working together on common problems-a type of project that appears to be increasing in importanco.

In his introduction, Dr. M. G. Candau, directorgeneral of the Organization, directs attention to the fact that in 1959 the Organization's work was carried on "against a general background of reduced tension in international affairs" and of "substantial improvement of economic conditions throughout the world, particularly in Europe" ; and he finds growing ovidence of the determination of world leaders to devote more of their countries' resources to help nations still in the early steps of technological and economic development to raise their standards of living.

In discussing some of the changes of emphasis in tho Organization's programmo, the director-general points out that communicable diseases remain ono of the world's most serious health problems. For some, more knowledgo is required; for others, such as malaria and smallpox, the methods are broadly known and what is wanted now is organization, trained. staff and money.

* Official Records of the World IIealth Organization, No. 98: The Work of WHO, 1959-Annual Report of the Dircctor-General to the World Mealth Assembly and to the United Nations. Pp. $\mathrm{x}+283$. (Geneva : World Health Organization; Jondon: H.M. Stationery
Office, 1960.) 6 Swiss francs; $10 s, 2$ dollars.
Among diseases calling for increased vigilance are the treponematoses. More than 100 million people still live in low-prevalence yaws areas, in several countries there has been a disturbing recrudescence of venereal syphilis, and a growing incidence of gonorrhœa has been found in 15 out of 22 countries surveyed. Investigations are being pursued in order to ensure that the most effective assistance can be given to countries combating these problems.

With tubereulosis, recent findings which show that domiciliary chemotherapy may for most cases be as efficacious as treatment in sanatoria are of particular importance to the many countries where there is an acute shortage of sanatoria beds.

Mention is also made of the newer developments against leprosy, bilharziasis, poliomyelitis and the zoonoses, and of preparatory work with the view of eradicating smallpox.

Much preparatory work has been done during the year for the expansion and intensification of the medical research programme. Main targets and priorities, established with the guidance of the Advisory Committee on Medical Resoarch, include the communicable diseases (with emphasis on viruses and diseases prevalent in tropical countries); for the highly industrialized countries, the chronic diseases, particularly cancer and cardiovascular troubles; nutrition, and problems of the increased risk of exposure to ionizing radiations. The 'service to research' will include standardization of nomenclature techniques and equipment, and the expansion of, the Organization's system of international reference centres.

Emphasis is also being given to the vast programme for the improvement of water supplies for communities, which is a primary objective in the attack on the enormous problems of environmental sanitation. The programmo will be carried out in collabora. tion with departments of public works and with public administrations and financial authorities.

Annexes to the report givo details of the mombership of the Organization, its Executive Board and expert committees; the main heads of the budget for 1959 ; and particulars of the secretariat structure and composition.

\section{THE METROPOLITAN WATER BOARD}

ONDON is by far the largest town in Britain 1 taking its raw water supplies from wolls in, or from rivers flowing through, a densoly populated and industrialized area, and the reports of tho Director of Water Examination of tho Metropolitin Water Board* are an invaluable guide to the measures which have to be taken, and the research which has to be carried out, to obtain a safo potablo wator from these sources.

The first necessity is, of course, to control and restrict pollution of the raw water. A good oxample

* Metropolitan Water Board. Thirty-Eighth Report on the Results of the Bacteriological, Chemical and Biological Examination of the London Waters for the years 1957-1958. 13y E. Windle Taylor. Pp. 114 + 4 plates, (London: Metropolitan Water Board, 1960.) 21s. of what ean be done is afforded by the River Lee ; in spite of the growth of both population and industry in the catchment area between 1948 and 1958, the quality of the river water improved substantially during that period. This was due in part to the improvement and extension of tho sewage works at Luton (including the provision of a final stage of treatment by rapid sand filtration or by microstraining), and in part to tho treatment of the sewage of scveral towns, including the new towns of Harlow and Stevenage, at a singlo works, diseharging to the Loo bolow the Board's Now Gauge intake.

Within the catchment area of the Thames there are three major establishmonts, at Harwoll, Aldormaston 